\title{
2005 - UM SÉCULO DEPOIS DO “NEURE ANSCHAUUNGEN"
}

A editoria de Química Nova recebeu esta carta do Prof. Henrique E. Toma, onde traça um paralelismo entre Albert Einstein e Alfred Werner, e relembra o centenário de sua obra, publicada em 1905, que mudou os rumos da Química Moderna.

Os Físicos elegeram 2005 o Ano Internacional da Física, homenageando Albert Einstein, em comemoração ao centenário dos artigos de sua autoria, que entraram para a história, incluindo a teoria especial da relatividade e do efeito fotoelétrico. Resgatando um feito semelhante na Química, em 1905, eu me atreveria a destacar a publicação da grande obra de Alfred Werner', "Neure Anschauungen auf dem Gebiete der Anorganischen Chemie", traduzida como "Uma nova concepção da Química Inorgânica", que fez renascer a Química dos Elementos Metálicos, logo depois de outra obra monumental "Lehrbuch der Stereochemie", que deu início à Estereoquímica Moderna. Por isso, Werner é considerado o pai da Química de Coordenação e também da Estereoquímica. Parece pouco? Se subtraíssemos os fundamentos de coordenação e de estereoquímica da Química atual, continuaríamos, com certeza, mergulhados em práticas arcaicas de cem anos atrás, desprovidos da visão estrutural e dos conceitos que levaram ao enorme avanço no desenvolvimento das reações, síntese, catálise, bioinorgânica, materiais e até mesmo ao surgimento da nanotecnologia molecular, na concepção de Jean-Marie Lehn.

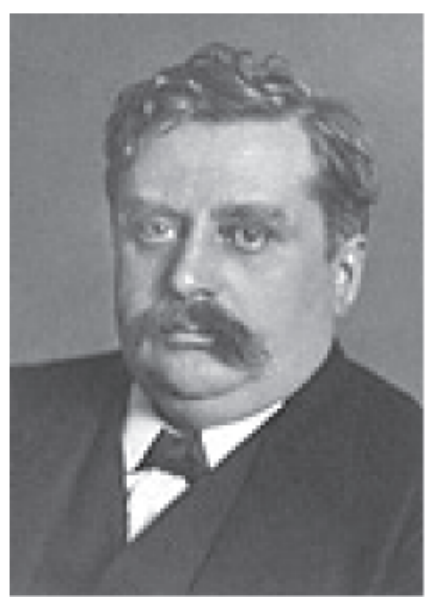

Alfred Werner (1866-1919)

Por outro lado, a história de Werner é tão rica e interessante, quanto a de Einstein. Ambos passaram pela famosa Eidgenössische Technische Hochschule Zürich (ETH Zürich), também conhecida como Escola Politécnica de Zurique, e foram agraciados com o Prêmio Nobel: Werner, em 1913 (em Química) e Einstein em 1921 (em Física). Um fato notável é que essa Escola produziu nada menos que 21 cientistas agraciados com o Prêmio Nobel, desde 1901!

Einstein tinha 26 anos quando criou a teoria da relatividade e a teoria sobre o efeito fotoelétrico, sendo esta última a que lhe rendeu o Nobel. Werner tinha apenas 24 anos quando criou a teoria da coordenação e da estereoquímica. Os criadores da mecânica quântica, De Broglie, Heisenberg, Schrödinger e Dirac, também não ficam atrás: eram todos muito jovens! Essa constatação fornece um elemento muito interessante para tentarmos entender como acontecem as revoluções científicas.
A Ciência é baseada em paradigmas, isto é, teorias e "verdades" que são compartilhadas pela comunidade científica. O desenvolvimento científico normal segue um padrão de continuidade, ditado por esses paradigmas; porém, de tempos em tempos pode ser quebrado pelo surgimento de algo novo, revolucionário. Quando isso ocorre, antigos paradigmas são descartados em função da aceitação de outros novos. Mas isso geralmente não acontece de forma suave. Toda revolução é precedida por períodos de crise, quando os paradigmas começam a mostrar suas falhas, embora normalmente no início, elas sejam ignoradas, com a argumentação que nada é perfeito! A história tem mostrado que o processo de criação de novos paradigmas privilegia mentes jovens ou cientistas novatos no campo, talvez por ainda não estarem impregnados dos paradigmas vigentes. Assim, contrastando com o perfil dos cientistas mais experientes e tradicionais, a revolução das idéias e gerações acaba gerando um confronto quase inevitável! Entretanto, os novos paradigmas sempre acabam se impondo, pois um elemento importante a eles associados, além da capacidade de explicar os problemas antigos e os que estão surgindo, é a possibilidade de vislumbrar perspectivas inéditas a serem exploradas. É isso que acaba estimulando o desenvolvimento da ciência.

No caso de Werner, a crise gerada pelo lançamento das teorias de coordenação e estereoquímica tornou-se parte da História, e ficou conhecida como "Controvérsia Jörgensen-Werner"2. Para entender isso, é importante destacar que tudo se passou em uma época (apenas um século atrás) em que a composição do átomo ainda era desconhecida, e as balanças, condutivímetros e termômetros eram os principais instrumentos de medida. Sophus Mads Jörgensen era um químico altamente respeitável, consagrado pelos seus trabalhos que explicavam a natureza dos chamados complexos, através das teorias de valência introduzidas por Kekulé para os compostos orgânicos, preservando inclusive as estruturas típicas de cadeias. Todo o conhecimento da época a respeito desses complexos enquadrava-se perfeitamente nas teorias vigentes. Então, por que criar problemas? Afinal, a Química não é uma só? Entretanto o jovem Werner ousou pensar além desses limites, substituindo a valência fixa pelo conceito de afinidade química, manifestada pelo elemento central como se fosse uma força de atração atuando sobre todos os demais ao seu redor. Nesse processo, o elemento central passaria a coordenar a entrada das espécies, que foram denominadas ligantes, e o resultado seria a formação de uma esfera de coordenação bem definida espacialmente. Surgiu assim um novo modelo estereoquímico, baseado nas características do elemento central e nas interações com as espécies circunvizinhas, assim como entre elas mesmas. Ao mesmo tempo, impôs-se o desafio de provar qual a geometria adotada pelos compostos. Enquanto isso não era possível, a lógica clássica de Jörgensen prevalecia sobre a imaginação fértil de Werner. Entretanto, com o passar do tempo, a situação foi se modificando a favor de Werner, intensificando ao mesmo tempo as controvérsias entre a nova e a velha escola, as quais se prolongariam por mais de uma década.

Se a teoria guia, a experiência decide! E essa foi a tática adotada por Werner. O modelo de coordenação explicava perfeitamente as observações feitas por Jörgensen sobre a natureza dos complexos; mas era superior em sua capacidade de prever a existência de 
isômeros espaciais (geométricos e ópticos) ainda desconhecidos. Ao mesmo tempo, conseguia explicar a ocorrência da isomeria óptica, considerada até então um atributo dos compostos orgânicos, ainda imersos no mito da força vital. Assim, quando seus discípulos conseguiram sintetizar os isômeros geométricos e ópticos previstos pelo modelo de coordenação, os antigos paradigmas foram definitivamente abandonados.

$\mathrm{Na}$ análise crítica dessa controvérsia, Jörgensen ganharia pontos ao defender os paradigmas tradicionais aceitos pela Química e pelo fato de buscar a explicação dos fatos através da experiência. Jörgensen atuou exatamente como preconiza a Ciência Moderna e o modelo de ensino seguido em todo o mundo. Werner, por sua vez, projetou sua criatividade ao imaginar algo novo, mais racional. Contudo, seus argumentos iniciais eram desprovidos de base experimental e não respeitavam os paradigmas vigentes. Com certeza, perderia em qualquer fórum de julgamento científico! Entretanto, mesmo assim acabou vencendo graças à capacidade de previsão de sua teoria e à tenacidade de seus discípulos em tentar prová-la. Desta forma, Werner mudou os rumos da Química no início do século passado.

Werner perpetuou-se através de sua Escola, e por ela passaram Heinrich Rheinboldt ${ }^{3}$, o fundador do Curso de Química na USP, e antigos mestres, como o saudoso Ernesto Giesbrecht ${ }^{4}$. Portanto, se a história continua, não podemos deixar de lembrar que também fazemos parte dela, compartilhando o significado especial deste ano de 2005, que poderia ser o Grande Ano da Química!

Henrique E. Toma

Instituto de Química, Universidade de São Paulo, CP 26077, 05513-970 São Paulo - SP e-mail: henetoma@iq.usp.br

\section{REFERÊNCIAS}

1. Shibata, Y.; Some personal recollections of Alfred Werner, in Werner Centennial, Adv. Chem. Ser. 1967, 62, 1.

2. Cohen, P. S.; Effect of the fixity of ideas on the Werner-Jörgensen controversy, in Werner Centennial, Adv. Chem. Ser. 1967, 62, 9.

3. Heinrich Rheinboldt iniciou sua carreira como Assistente do Prof. Paul Pfeiffer, ex-aluno de Werner, acompanhando sua trajetória na Escola Técnica Superior de Karlsruhe, e depois na Universidade de Bonn, onde se consagrou como Professor de Química, permanecendo no cargo até 1933. Com a instalação do regime nazista na Alemanha, Rheinboldt mudouse para o Brasil, a convite do Governo de São Paulo, para implantar o Departamento de Química na recém criada Universidade de São Paulo.

4. Ernesto Giesbrecht foi Professor de Química Inorgânica do IQUSP e discípulo de Heinrich Rheinboldt. Ele fez seu primeiro pós-doutorado com Paul Karrer, na famosa ETH Zurich. Karrer, considerado um dos mais notáveis discípulos de Werner, também foi agraciado com o Prêmio Nobel de Química em 1937. 